\title{
A Critical Review of Models of the H-2/H2O/Ni/SZ Electrode Kinetics
}

\author{
Mogensen, Mogens Bjerg; Høgh, Jens Valdemar Thorvald; Hansen, Karin Vels; Jacobsen, Torben
}

Published in:

E C S Transactions

Link to article, DOI:

$10.1149 / 1.2729236$

Publication date:

2007

Document Version

Publisher's PDF, also known as Version of record

Link back to DTU Orbit

Citation (APA):

Mogensen, M. B., Høgh, J. V. T., Hansen, K. V., \& Jacobsen, T. (2007). A Critical Review of Models of the H

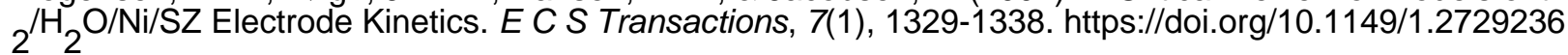

\section{General rights}

Copyright and moral rights for the publications made accessible in the public portal are retained by the authors and/or other copyright owners and it is a condition of accessing publications that users recognise and abide by the legal requirements associated with these rights.

- Users may download and print one copy of any publication from the public portal for the purpose of private study or research.

- You may not further distribute the material or use it for any profit-making activity or commercial gain

- You may freely distribute the URL identifying the publication in the public portal

If you believe that this document breaches copyright please contact us providing details, and we will remove access to the work immediately and investigate your claim 


\title{
A Critical Review of Models of the $\mathrm{H}_{2} / \mathrm{H}_{2} \mathrm{O} / \mathrm{Ni} / \mathrm{SZ}$ Electrode Kinetics
}

\author{
M. Mogensen ${ }^{\mathrm{a}}$, J. Høgh ${ }^{\mathrm{a}}$, K. V. Hansen ${ }^{\mathrm{a}}$, and T. Jacobsen ${ }^{\mathrm{b}}$ \\ ${ }^{a}$ Fuel Cells and Solid State Chemistry Department, Risø National Laboratory, The \\ Technical University of Denmark, DK-4000 Roskilde, Denmark \\ ${ }^{b}$ Department of Chemistry, The Technical University of Denmark, DK-2800 Lyngby, \\ Denmark
}

\begin{abstract}
Various models of the $\mathrm{H}_{2} / \mathrm{H}_{2} \mathrm{O} / \mathrm{Ni} / \mathrm{SZ}(\mathrm{SZ}=$ stabilized zirconia) electrode kinetics have been presented in the literature in order to explain the reported experimental data. However, there has been a strong tendency of using a limited set of data to "verify" a given model, disregarding other data sets, which do not fit the model. We have inspected some models in the literature, and problems (e.g. no quantitative model has explained the large variation in reported values of apparent activation energy of the electrode kinetics) as well as strengths of the models are discussed. We point out experimental findings that a useful model must be able to explain such as difference in sensitivity to poisoning by $\mathrm{H}_{2} \mathrm{~S}$ due to differences in the detailed composition of the SZ and large change in apparent activation energy by change in cermet preparation. Finally, we will point out some elements, which seem important for any realistic and useful mathematical model of the $\mathrm{H}_{2} / \mathrm{H}_{2} \mathrm{O} / \mathrm{Ni} / \mathrm{SZ}$ electrode.
\end{abstract}

\section{Introduction}

Modeling of SOFC electrodes has been performed on different levels. The purpose may differ significantly as some of the models are of the engineering type that are useful for the understanding of practical features such as the relation between electronic conductivity of a Ni-YSZ-cermet and the volume percent of $\mathrm{Ni}$, the particle size and distribution etc, see e.g. (1-5). Such models are quite useful, but are limited by the limited basic understanding of the electrochemical electrode kinetics. Other models have the purpose to describe the detailed kinetics, i.e. the physics and chemistry of the electrode processes. These models (qualitative as well as quantitative) are the subject of this paper. They are subject to significant controversy, because the scientific understanding of the $\mathrm{H}_{2} / \mathrm{H}_{2} \mathrm{O} / \mathrm{Ni} / \mathrm{SZ}$ electrode is still rather poor as evidenced by the large discrepancies in the experimental data in the literature as pointed out below.

A large number of original works and several reviews of experimental SOFC anode data and anode models have been published over time (6-20 just to mention a few). Most of these references also contain proposals for electrode mechanisms, which could be the basis for mathematical models even though such were not always formulated. Most of the reviews just list what has been reported without any critical discussion.

The reported measured data are - at least apparently - so much in disagreement that it seems tempting to use a limited set of data to "verify" a given model, disregarding other data sets, which do not fit the model. This is unfortunate as it mainly contributes to 
increasing the confusion. We have critically inspected models from the literature, and problems as well as strengths of the models are discussed. For example, no quantitative model has explained the large variation in reported values of apparent activation energy of the electrode kinetics.

One main general problem is that none of the models take into account that free surfaces of the stabilized zirconia (SZ) after few hours at temperatures around $500^{\circ} \mathrm{C}$ or above, always are covered by a segregated "mono-layer" of silica containing material. The driving force for the formation of this layer will be pointed out as the high surface energy of formation of really clean zirconia. This surface energy is equal to the fracture energy associated with spontaneous fast crack growth in the SZ.

Another general problem is the varying degree of acceleration of the hydrogen oxidation kinetics by water partial pressure together with a small effect of hydrogen partial pressure. A model, which explains this in very simple terms, has been proposed. We will argue that this model can at least not be generally valid.

First, we present the main type of reaction mechanisms reported so far. Next, we point out differences in experimental findings that a useful model must be able to explain such as differences in the effect of $P_{\mathrm{H}_{2} \mathrm{O}}$ (steam partial pressure), in sensitivity to poisoning by $\mathrm{H}_{2} \mathrm{~S}$, and in activation energy depending on the detailed composition and structure of the porous Ni-SZ composite electrode. Some qualitative explanations to these differences are offered. Based on this, we discuss selected models. Finally, we list some of the elements, which seem to be necessary in a realistic mathematical model of the $\mathrm{H}_{2} / \mathrm{H}_{2} \mathrm{O} / \mathrm{Ni} / \mathrm{SZ}$ electrode.

\section{Proposed Mechanisms and Experimental Data}

Mechanisms and the Appearance of the 3PB.

Several models of the $\mathrm{H}_{2} / \mathrm{H}_{2} \mathrm{O} / \mathrm{Ni} / \mathrm{SZ}$ electrode kinetics have been presented in order to explain the reported experimental data. The main types of proposed mechanisms are shown in Fig. 1a) to c), and Fig. 1d) depicts the presence of segregated impurities that always seem to be present even in rather pure systems.

The idea of proton migration (Fig. 1a) being the main mechanism of charge transfer has been advocated by many. We argued that this mechanism might be the most probable based on general knowledge about the interaction between $\mathrm{Ni}$ and $\mathrm{H}_{2}(12,14)$, but we did not have strong direct electrochemical evidence. The oxide ion migration (Fig. $1 \mathrm{~b}$ ) was advocated by Mizusaki et al. $(10,13)$ based on data from pattern electrodes, but the data could also be interpreted by a "Fig. 1a)"-type of mechanism (14). Reaction of $\mathrm{H}_{2}$ by $\mathrm{O}^{2-}$ directly on the SZ electrolyte followed by electron migration through the SZ to the Ni has been mentioned as a possibility $(11,21)$ without strong experimental evidence.

During the 1990's all authors dealing with the Ni-SZ electrode apparently assumed that all surfaces were clean or at least open for direct reaction between relevant species. We assumed this, even though available data strongly indicated that this might not be the case (22). The gradually increasing body of available experimental data on the Ni-YSZ 
(yttria stabilised zirconia) electrode pointed more and more to the fact that nominal equal electrodes actually had to be very different, and that this most probably is due to differences in the impurities (and electrolyte components) segregated to the 3PB (23). Now strong evidence for a picture of the Ni-SZ 3PB like Fig. 1d) exists (24-26).
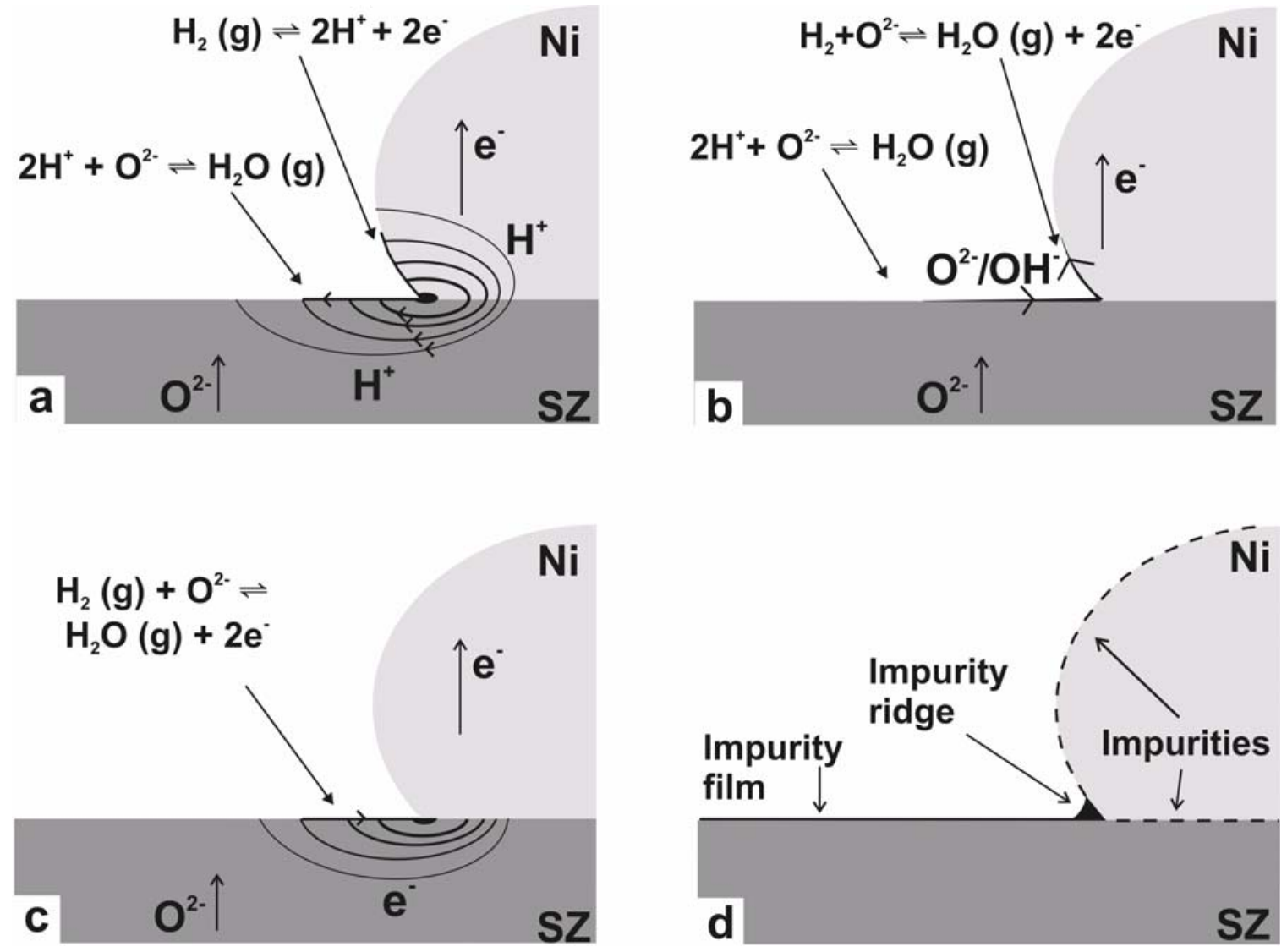

Figure 1. a) - c) show sketches of possible reaction paths discussed in the literature, and d) summarises the observations of impurity segregations at and near the three phase boundary (3PB); a) $\mathrm{H}_{2}$ adsorption on the Ni results in the formation of $\mathrm{H}^{+}$ions, which migrate to the site for water formation along the surfaces or though bulk Ni and bulk SZ. b) Migration of $\mathrm{O}^{2-}$ or $\mathrm{OH}^{-}$from the $\mathrm{SZ}$ to the $\mathrm{Ni}$ along surfaces to the water formation site at the Ni. c) Water formation takes place at the SZ surface, and electron transport to the Ni at the surface of or through the SZ is occurring. d) Impurities are found at all surfaces and interfaces: an impurity film fully covers the SZ surface, an impurity ridge is located at the $3 \mathrm{~PB}$, and impurities appear at the Ni surface and Ni-SZ interface, but these seem not to cover the Ni surface and interface totally.

$\underline{\text { Segregation to the SZ Surface and the Ni-SZ 3PB. }}$

The mechanical energy release rate by fast fracture of $8 \mathrm{YSZ}$ has been determined to $8.0 \mathrm{~J} \mathrm{~m}^{-2}$ (27). This energy release rate is believed to be equal to the surface energy of a clean 8 YSZ surface with no restructuring compared to the crystal structure. $8 \mathrm{~J} \mathrm{~m}^{-2}$ is equal to ca. $630 \mathrm{~kJ} \mathrm{~mol}^{-1}$ of cations at the surface of a (100) crystal plane. This should be compared to the Gibbs free energy of formation of $\mathrm{ZrO}_{2}$, which is around $1030 \mathrm{~kJ} \mathrm{~mol}^{-1}$ 
$\mathrm{ZrO}_{2}$. In other words, the surface energy of a really clean unrelaxed SZ surface is very high and this implies a strong driving force for all kinds of processes, which may screen the dangling oxide (or zirconium) ions at the $\mathrm{SZ}$ surface. It seems that $\mathrm{SiO}_{2}$ is one of the chemical substances, which has a very high affinity to the SZ surface. For very clean SZ with $\mathrm{SiO}_{2}$ concentrations below the solubility limit only a monolayer of "silicate glass" is formed, whereas in case of more impure SZ with silica in the grain boundaries, particles and even larger features like the ridge at the 3PB may form.

The silica impurity film at SZ surface and the ridge at the 3PB imply that electrochemical reactions like those in figures 1a)-1c) must take place either through this phase or around it. The mobility of the different species in the surface glass is unknown and different from mobility in bulk SZ. It should be noted that even on a polished YSZ single crystal with less than $10 \mathrm{ppm} \mathrm{SiO}_{2} 74 \%$ of the surface was covered with a monolayer of silica and other impurities after 1 hour at $500^{\circ} \mathrm{C}(28)$. In other words, those who looked for an impurity layer on the YSZ surface (after it has been exposed to SOFC temperatures for a short while) with appropriate tools always found it.

\section{Interpretation of Experimental Data}

In this section we first describe the dependence of the electrode reaction rate on temperature, polarization and potential. Next, we present data on dependence on gas concentrations, and finally, some observations on effects of isotopes and additives, and of poisoning with $\mathrm{H}_{2} \mathrm{~S}$.

Dependence on Temperature and Potential. Large variations in activation energy from 0.6 to $1.7 \mathrm{eV}$ have been reported for both for cermets and model Ni electrodes on SZ, as well as large variations in the polarization resistance, $R_{p}$ at given conditions. For cermets the polarization resistance is very dependent on the structure of the Ni-SZ composite (porosity, particle size and size distribution), but also on the raw material and fabrication details $(11,20,23)$. Thus, it is difficult to compare and even to reproduce cermet data, and therefore many experiments on model electrodes (Ni points or patterns) have been presented in the literature. Fig. 2 shows an Arrhenius plot in which a number of data sets from different sources have been plotted. It is clear that model electrodes are not easily reproducible either, as the results span 3 - 4 decades at given temperatures. It should be noted that the data named "Høgh polarized" are from a Ni-SZ electrode that was polarized cathodically to $-2000 \mathrm{mV}$ vs. Pt/air, i.e. the electrode was "blackened". This decreases $R_{p}$ with a factor of 10-100, and the apparent activation energy with more than a factor of 2 . The effect is assumed to be due to reduction of all or some of the impurities at the $3 \mathrm{~PB}$.

The polarization curves (i-V-curves) are usually relatively linear, and even though the polarization curves are occasionally plotted as Tafel plots, there is not much indication of any kind of Tafel type kinetics as the curves in the Tafel plot almost always are very nonlinear. The tendency for the polarization curves of the $\mathrm{H}_{2} / \mathrm{H}_{2} \mathrm{O} / \mathrm{Ni} / \mathrm{SZ}$-electrodes seems to be in a simple linear plot that a small nicely linear region of ca $\pm 25 \mathrm{mV}$ exists around the OCP. The current density increases more than linear over the next 50-150 mV in anodic direction and then it becomes about linear again on further polarization. In case of high performance Ni-SZ-cermets, the current stabilizes almost immediately on potential changes, whereas Ni point electrodes are responding over minutes and most often the 
current density is rather unstable at anodic polarizations. Sometimes more or less regular oscillations of the current density at constant potential are observed.

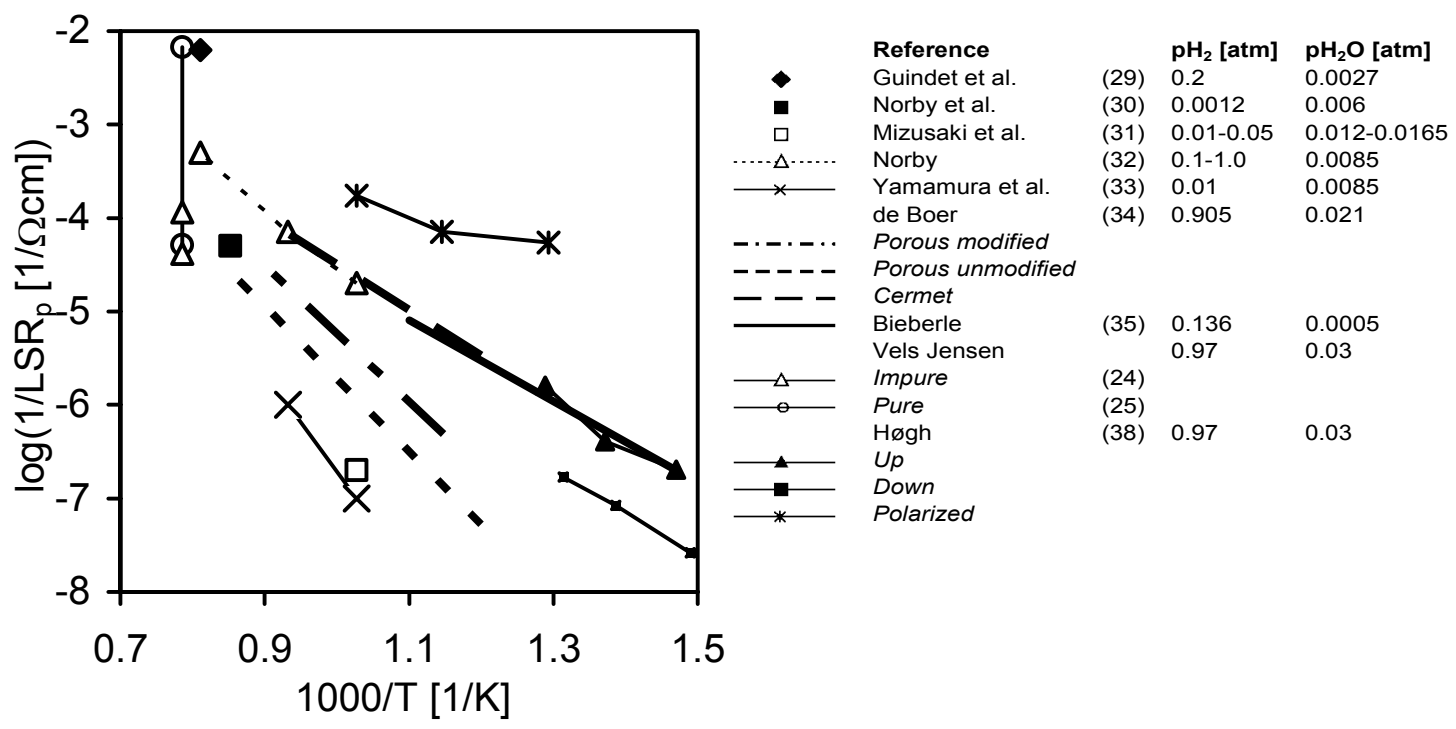

Figure 2. Arrhenius plots for selected results for Ni-SZ electrodes. $\mathrm{LSR}_{\mathrm{p}}$ is length specific polarization resistance.

Dependence on Partial Pressure of Reactants. The dependence of the rate of a given reaction on concentration of reactants is usually described by reaction orders. Most NiYSZ electrode data are, however, presented as polarization resistance at open circuit potential (OCP). Often the dependence of $\mathrm{R}_{\mathrm{p}}$ on partial pressure of $\mathrm{H}_{2}$ and of $\mathrm{H}_{2} \mathrm{O}$ is erroneously called reaction order. Let us therefore briefly present the correct theory before summarizing data on the partial pressure dependences.

The total current density, $i$, is given as the sum of the anodic current density, $i_{+}$, and the cathodic current density, $i_{-}$, as shown by equation [1]:

$$
i=i_{+}+i_{-}
$$

This shows that it is not meaningful to talk about a reaction order at zero net current (OCP), because two oppositely directed reactions take place.

The reaction orders at a given temperature, $p_{r}$ and $p_{o}$, for given gaseous component are defined by eq. [2] for an anode process reactant (subscript $r$ for reduced species) and by eq. [3] for a cathode process reactant (subscript o for oxidized species) under the condition of ideality $(36,37)$. This condition is believed to be fulfilled with good approximation for species like $\mathrm{H}_{2}, \mathrm{H}_{2} \mathrm{O}$ and $\mathrm{O}_{2}$ at temperatures above $500^{\circ} \mathrm{C}$. The measured current density, $i$, is only approximately equal to $i_{+}$or $i_{-}$for overpotentials far away $(200-300 \mathrm{mV})$ from OCP.

Thus, in order to derive the reaction order we must measure the current densities far away from the open circuit potential of the electrode. Also note, that everything apart from the partial pressure of the species in question must be constant including the electrode potential, $\varepsilon$, measured against a well defined reference electrode. 


$$
\begin{aligned}
& \left(\frac{\partial \log i_{+}}{\partial \log P_{h}}\right)_{j \neq h, \varepsilon}=p_{r, h} \\
& \left(\frac{\partial \log \left|i_{-}\right|}{\partial \log P_{k}}\right)_{j \neq k, \varepsilon}=p_{o, k}
\end{aligned}
$$

When all relevant reaction orders are determined then the anodic and cathodic current densities can be described by eqs. [4] and [5]

$$
\begin{aligned}
& i_{+}=k_{+} \prod P_{j}^{p_{r, j}} f(\varepsilon) \\
& i_{-}=-k_{-} \prod P_{j}^{p_{o, j}} g(\varepsilon)
\end{aligned}
$$

where $f(\varepsilon)$ and $g(\varepsilon)$ are functions of the electrode potential, $\varepsilon . k_{+}$and $k_{-}$are temperature dependent constants. These functions also have to be determined experimentally. We do not have any general physical law from which we can derive $f(\varepsilon)$ and $g(\varepsilon)$. It looks as if many authors believe that the Butler-Volmer equation is a general relation describing $\mathrm{i}-\mathrm{V}$ relations, but this equation is only describing the current density - overpotential relation in case charge transfer over one (or few) well defined energy barrier(s) is the only rate determining step. Thus, in case of oxidation of $\mathrm{H}_{2}$ and reduction of $\mathrm{H}_{2} \mathrm{O}$ according to

$$
\mathrm{H}_{2}(\text { gas })+\mathrm{O}^{2-}(\mathrm{SZ}) \leftrightarrows \mathrm{H}_{2} \mathrm{O}(\text { gas })+2 \mathrm{e}^{-}(\mathrm{Ni})
$$

and at open circuit potential, where $i=0$, we get using equations [1], [4] and [5]

$$
i_{0}=i_{+}=k_{+} P_{H_{2}}^{p_{H_{2}}} f(\varepsilon)=\left|i_{-}\right|=-k_{-} P_{\mathrm{H}_{2} \mathrm{O}}^{p_{\mathrm{H}_{2} \mathrm{O}}} g(\varepsilon)
$$

When we change $P_{\mathrm{H}_{2}}$ and/or $P_{\mathrm{H}_{2} \mathrm{O}}$ the open circuit electrode potential (the equilibrium potential), $\varepsilon$, will change according to the Nernst equation, but as we do not know the functions $f(\varepsilon)$ and $g(\varepsilon)$, we cannot relate $i_{0}$ to the reaction orders.

It is occasionally assumed that $i_{0}$ is at least approximately proportional to power functions of the partial pressures, i.e.

$$
i_{0}=k_{1} P_{H_{2}}^{m} P_{H_{2} \mathrm{O}}^{n}
$$

and as

$$
R_{p}=k_{2} \frac{R T}{i_{0}}
$$

this implies that

$$
R_{p}=k_{3} P_{H_{2}}^{-m} P_{H_{2} O}^{-n}
$$




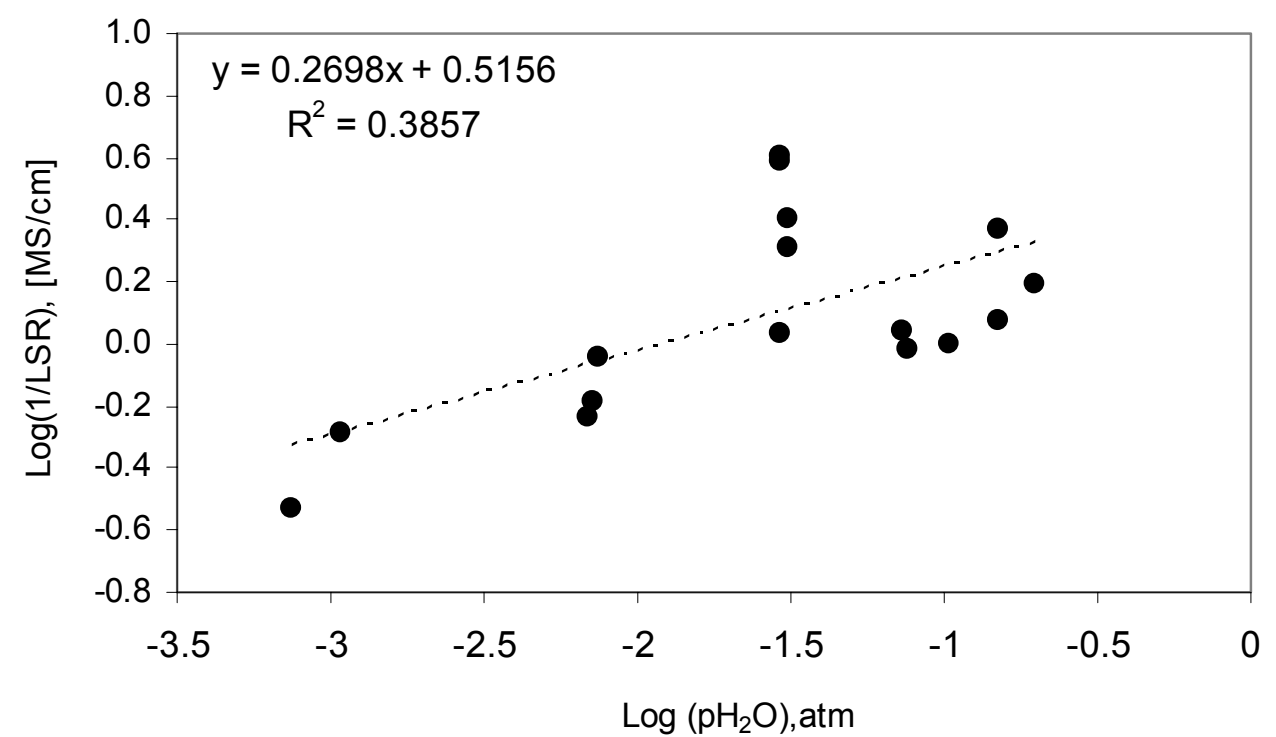

Figure 3. A double logarithmic plot of the experimental dependence of $1 / L S R_{p}$, (length specific $R_{p}$ ), which is proportional to the exchange current density (eq. [9]), on $P_{\mathrm{H}_{2} \mathrm{O}}$. From Høgh (38). The slope of the line is (i.e. $n$ in eq. [10]) $0.27 \pm 0.09$. Note that in some cases $P_{H_{2}}$ has been varied too, and in other cases the electrode potential changed.

The assumptions of eq. [8] and thus of eq. [10] are basically wrong in the context of the $\mathrm{H}_{2}-\mathrm{H}_{2} \mathrm{O}-\mathrm{Ni}$-SZ-electrode, because $P_{\mathrm{H}_{2} \mathrm{O}}$ cannot be varied at OCP unless either the electrode potential or $P_{\mathrm{H}_{2}}$ is also varied. Actually, the correlation of eq. [10] is not always coming out with a convincing result as shown in Fig. 3, but the fact that a fair correlation is occasionally observed probably means that $R_{p}$ is much more sensitive to $P_{\mathrm{H}_{2} \mathrm{O}}$ than to electrode potential and $P_{H_{2}}$ within the ranges investigated.

Values of $\mathrm{m}$ from -0.5 to +1 and of $n$ from 0 to 0.7 have been found $(13,19,21)$, but constant $m$ and $n$ values are not always seen.

Other Important Observations. H/D isotope effect is significant below $850^{\circ} \mathrm{C}$, increasing with decreasing temperature (39). This indicates that diffusion or migration of protons is involved as a rate limitation of the electrode reaction. A significant accelerating effect on the electrode kinetics by a small addition of manganese oxide (39) may be explained by the interaction between manganese oxide and the glassy impurities. It is also important to note that there is a significant effect of changing the $\mathrm{Ni}$ to other metals (e.g. $\mathrm{Au}, \mathrm{Cu}$ ) or ceramic electron conductors. $\mathrm{Ni}$ is significantly better than most other metals. This shows that the electrode reaction is not fully controlled by the segregated impurities. It is furthermore remarkable that $\mathrm{CO}$ may be oxidized and $\mathrm{CO}_{2}$ reduced with up to similar rates as $\mathrm{H}_{2}$ and $\mathrm{H}_{2} \mathrm{O}$ (but often somewhat slower).

Finally, a recently observed strong effect of the electrolyte composition on the sensitivity to sulphur poisoning is pointed out. While an SOFC with a Ni-YSZ-cermet electrode totally lost its voltage in less than $1 \mathrm{~h}$ in a test at $800{ }^{\circ} \mathrm{C}$ using $\mathrm{H}_{2}$ with $20 \mathrm{ppm}$ $\mathrm{H}_{2} \mathrm{~S}$ as fuel, a Ni-SSZ (scandia stabilized zirconia)-cermet operated stably at almost 600 $\mathrm{mV}\left(200 \mathrm{~mA} \mathrm{~cm}^{-2}\right)$ with $100 \mathrm{ppm} \mathrm{H}_{2} \mathrm{~S}(40)$. This points to a mechanism of the "Fig. 1c)"type, but most probably through an impurity film. 


\section{Discussion of Models}

Especially two groups have published relatively detailed models, and these will be used as examples in our discussion of models. Bieberle et al. used the so-called "Spacestate model" to model some of the results of her own Ni-pattern electrodes (41). A lot of simplifying assumptions were done, so naturally it could not model the experiments to any appreciable extent. Our assessment is that an important erroneous assumption is that simple charge transfer is the main rate limiting step. Furthermore, no attempt to explain other data than her own was made, and it was not recognized that probably also her electrode surfaces and 3PB are not clean. If so, it would have been reasonable to assume some kind of rate limitation due to diffusion of reactants through and/or around the impurity barriers.

Another very comprehensive modeling work is being carried out by Bessler et al. (42). Even though this work and the preceding papers are discussing the assumptions used in great detail, our main objection is their assumption that charge transfer (as described by the Butler-Volmer equation) is the only rate limiting step. Furthermore, the model was only used to describe the data of Bieberle et al. (19), and the model was only able to describe these data to a limited degree. In spite of this it is claimed that the model proves that the effect of water is a simple effect of the change of electrode potential with the change of $P_{\mathrm{H}_{2} \mathrm{O}}$. The modeling result is presented as if the effect of electrode potential on the reaction rate is a kind of new discovery and that other workers were not aware of this general possibility. However, most have been very much aware of this and realized that this was not the explanation of the varying effect of water. Recently, Høgh did a series of experiments with Ni point electrodes on SZ single crystals (an extremely pure system) that showed no effect of $P_{\mathrm{H}_{2} \mathrm{O}}$ on the hydrogen evolution reaction but a strong accelerating effect of $P_{\mathrm{H}_{2} \mathrm{O}}$ on the hydrogen oxidation $(38,43)$. This clearly demonstrates that the accelerating effect of $P_{\mathrm{H}_{2} \mathrm{O}}$ is at least not always related to changes in the OCP. Furthermore, Bessler et al. do not give any explanation of why so different effects are reported, or why the data of Bieberle at al. should be of a higher quality that other data. As a final comment we want to encourage that no new terms like "Nernst potential effects" is used for well known phenomena, which were described using different terms in as well old as new text books. This just adds to the confusion. Likewise the imprecise term of "spillover" (borrowed from catalysis science) should be avoided in cases where it as in (42) obviously means charge transfer.

\section{$\underline{\text { Requirements to Models Based on Experimental Data }}$}

It is a reasonable requirement that a model should be able to reflect all reliable experimental data. This takes a flexible model, which can be adapted to the actual details of a given $\mathrm{H}_{2} / \mathrm{H}_{2} \mathrm{O} / \mathrm{Ni} / \mathrm{SZ}$ electrode, as most of the reported data are, actually, for different electrodes, even though they are nominally of the same type. Naturally, much finer experimental details should be made available in order to develop and verify such models.

Further, a quantitative model should preferably (like a useful hypothesis) be able to predict clear consequences and thus give clear guidelines to the experimentalists. 


\section{Concluding Remarks}

The results available today indicate that many of the elements sketched in Fig. 1 have to be taken into account in a realistic model in some kind of combination. Much more detailed measurements are still needed in order to resolve this issue. Especially, we think that more detailed experimental investigations of the 3PB structure and composition down to at least close to atomic scale is needed. Further, more reliable data on species, including a lot of impurity species, on both the Ni surface and the SZ surface are needed. These data may be generated both from quantum chemical calculations (density function theory), and from experiments. Free energy of a given species may be measured by measuring the vapor pressure of that species, and physical properties like conductivity of impurity layers should be measured in situ.

\section{Acknowledgments}

Financial support from Energinet.dk through PSO-R\&D-project no. 2006-1-6493 is gratefully acknowledged.

\section{References}

1. S. Sunde, Electrochim. Acta, 42, 2637 (1997).

2. S. Sunde, J. Electroceram. 5, 153 (2000).

3. C.W. Tanner, K.-Z. Fung, and A.V. Virkar, J. Electrochem. Soc., 144, 21 (1997).

4. P. Costamagna, E. Arato, P.L. Antonucci, and V. Antonucci, Chem. Eng. Sci., 51, 3013 (1996).

5. A. S. Ioselevich and A. A. Kornyshev, Fuel Cells, 1, 40 (2001).

6. V.N. Chebotin, M.V. Glumov, A.D . Neuimin, and S. F. Palguev, Sov. Electrochem. 7, 55 (1971).

7. T. Kawada et al., J. Electrochem. Soc., 137, 3042 (1990).

8. T. Kawada, N. Sakai, H. Yokokawa, and M. Dokiya, Solid State Ionics, 40/41, 402 (1990).

9. M. Mogensen and T. Lindegaard, in SOFC-III, S. C. Singhal and H. Iwahara, Editors, PV 93-4, p. 484, The Electrochemical Society Proceedings Series, Pennington, NJ (1993).

10. J. Mizusaki et al., Solid State Ionics, 70/71 52 (1994).

11.N.Q. Minh and T. Takahashi, Science and Technology of Ceramic Fuel Cells, Elsevier, Amsterdam (1995).

12. S. Skaarup, B. Zachau-Christiansen and T. Jacobsen, in Proc. $17^{\text {th }}$ Risø Internat. Symp. Mat. Science, F. W. Poulsen et al., Editors, p. 423, Risø National Laboratory, Roskilde, Denmark (1996).

13. J. Mizusaki et al., in Proc. $17^{\text {th }}$ Risø Internat. Symp. on Mat .Science, F. W. Poulsen et al., Editors, p. 363, Risø National Laboratory, Roskilde, Denmark (1996).

14. M. Mogensen, S. Sunde, S. Primdahl, in Proc. $17^{\text {th }}$ Risø Internat. Symp. on Mat. Science, F. W. Poulsen et al., Editors, p. 77, Risø National Laboratory, Roskilde, Denmark (1996).

15. J. Divisek, A. Kornyshev, W. Lehnert, U. Stimming, I.C. Vinke, and K. Wippermann, in SOFC-V, U. Stimming, S. C. Singhal, H. Tagawa, and W. Lehnert, Editors, PV 9740, p. 606, The Electrochemical Society Proceedings Series, Pennington, NJ (1997). 
16. F.Z. Mohamedi-Boulenouar, J. Guindet, A. Hammou, in $S O F C-V$, U. Stimming, S. C. Singhal, H. Tagawa and W. Lehnert, Editors, PV 97-40, p. 441, The Electrochemical Society Proceedings Series, Pennington, NJ (1997).

17. P. Holtappels, L.G.J. de Haart, and U. Stimming, J. Electrochem. Soc., 146, 1620 (1999).

18. P. Holtappels, I.C. Vinke, L. G. J. de Haart, and U. Stimming, J. Electrochem. Soc., 146, 2976 (1999).

19. A. Bieberle, L.P. Meier and L.J. Gauckler, J. Electrochem. Soc., 148, A646 (2001).

20. A.J. McEvoy, in High temperature solid oxide fuel cells: Fundamentals, design and application, S. C. Singhal, K. Kendall, Editors, p. 229, Elsevier, Oxford (2003).

21. S. Primdahl, Ph.D. Thesis, Risø-R-1137(EN), Risø National Laboratory, Roskilde, Denmark (1999).

22. S.P.S. Badwal and J. Drennan, in Science of Ceramic Interfaces II, J. Nowotny, Editor, p. 71, Elsevier (1994).

23. M. Mogensen et al., Solid State Ionics, 150, 123 (2002).

24. K.V. Jensen et al., Solid State Ionics, 144, 197 (2001).

25. K.V. Jensen et al., Solid State Ionics, 160, 27 (2003).

26. K.V. Hansen et al., J. Electrochem. Soc., 151, A1436 (2004).

27. A.N. Kumar and B.F. Sørensen, J. Am. Ceram. Soc., 83, 1199 (2000).

28. M. de Ridder, A.G.J. Vervoort, R.G. van Welzenis and H.H. Brongersma, Solid State Ionics, 156, 255 (2003).

29. J. Guindet, C. Roux, A. Hammou, in Proc. $2^{\text {nd }}$ Internat. Symp. on SOFC, P. Grosz, P. Zegers, S.C. Singhal, O. Yamamoto, Editors, p. 553, Athens, Greece (1991).

30. T. Norby, O.J. Velle, H. Leth-Olsen and R. Tunold, in SOFC III, S. C. Singhal and H. Iwahara, Editors, p. 473, PV 93-4, The Electrochemical Society Proceedings Series, Pennington, NJ (1993).

31. J. Mizusaki et al., in SOFC III, S.C. Singhal and H. Iwahara, Editors, p. 533, PV 93-4, The Electrochemical Society Proceedings Series, Pennington, NJ (1993).

32. T. Norby, in Proc. $2^{\text {nd }}$ European SOFC Forum, B. Thorstensen, Editor, p. 607, Oslo, Norway (1996).

33. T. Yamamura et al., Proc. $2^{\text {nd }}$ European SOFC Forum, B. Thorstensen, Editor, p. 617 , Oslo, Norway (1996).

34. A. de Boer, Ph.D. Thesis, University of Twente, The Netherlands (1998).

35. A. Bieberle, Ph.D. Thesis, Swiss federal Institute of Technology, Switzerland (2000).

36. K. J. Vetter, Electrochemical Kinetics, p. 432 ff, Academic Press, New York (1967).

37. J.O'M. Bockris and A.K.N. Reddy, in Modern Electrochemistry, p. 1008 ff, Plenum Press, New York (1970).

38 J. Høgh. Ph. D. Thesis, Risø-Ph.D-22(EN), www.risoe.dk/rispubl/AFM/ris-phd22.htm., Risø National Laboratory, Roskilde, Denmark (2005).

39. S. Primdahl and M. Mogensen, in SOFC-VI, S.C. Singhal and M. Dokiya, Editors, PV 99-19, p. 530, The Electrochemical Society Proceedings Series, Pennington, NJ (1999).

40. K. Sasaki et al., J. Electrochem. Soc., 153, A2023 (2006).

41. A. Bieberle and L.J. Gauckler, Solid State Ionics, 146, 23 (2002).

42. W.G. Bessler, J. Warnatz and D.G. Goodwin, Solid State Ionics, 177, 3371 (2007).

43. J. Høgh, K.V. Hansen and M. Mogensen, in Proc. $26^{\text {th }}$ Risø Internat. Symp. Mat.

Science, S. Linderoth et al., Editors, p. 235, Risø National Laboratory, Roskilde, Denmark (2005). 